Volume 1, Nomor 1, September 2020, 1-8

BEMAS: JURNAL BERMASYARAKAT

p ISSN 27455866 | e ISSN xxxx xxxx

\title{
MANAJEMEN PENGELOLAAN WEBSITE DALAM RANGKA PEMBERDAYAAN PELAJAR SEKOLAH MENENGAH KEJURUAN MUHAMMADIYAH 2 CILEUNGSI
}

\author{
Mohamad Anas Sobarnas ${ }^{1 *}$, Mustopa Idris ${ }^{2}$, Nurkholis ${ }^{3}$, Ashari Imamuddin ${ }^{4}$ \\ ${ }^{1 * 3,4}$ Program Studi Teknik Informatika, Sekolah Tinggi Teknologi Muhammadiyah Cileungsi, Cileungsi, Bogor, \\ Jawa Barat, Indonesia 16820 \\ ${ }^{2}$ Program Studi Teknik Industri, Sekolah Tinggi Teknologi Muhammadiyah Cileungsi, Cileungsi, Bogor, Jawa \\ Barat, Indonesia 16820
}

Email:*anas@sttmcileungsi.ac.id, mustopa@sttmcileungsi.ac.id, nurkholis@sttmcileungsi.ac.id ashari@sttmcileungsi.ac.id

\section{INFORMASI ARTIKEL}

\section{Article History:}

Submission: 01-08-2020

Revised: 27-08-2020

Accepted: 19-09-2020

Published: 30-09-2020

* Korespondensi:

Mohamad Anas Sobarnas anas@sttmcileungsi.ac.id

\begin{abstract}
ABSTRAK
Setiap tahun SMK Muhammadiyah 2 Cileungsi meluluskan kurang lebih 200 siswa, berdasarkan hasil wawancara dari dengan beberapa alumni bahwa tidak semua siswa lulusan sekolah langsung terserap oleh dunia industri. SMK Muhammadiyah 2 Cileungsi sudah mencoba mencari solusi dengan cara menggandeng beberapa industri untuk menyerap tenaga lulusannya, namun hal ini dirasa masih belum cukup untuk meningkatkan daya serap lulusan, untuk bisa langsung memiliki penghasilan. Adapun tujuan dari kegiatan Pengabdian kepada Masyarakat (PkM) ini adalah bagaimana dosen dan mahasiswa Sekolah Tinggi Teknologi Muhammadiyah Cileungsi dapat berkontribusi kepada masyarakat khususnya bagi mahasiswa vokasi untuk membantu mengasah dan meningkatkan ilmu pengetahuan dibidang ilmu pemrograman website, kegiatan ini merupakan bagian dari sebagai upaya peningkatan soft skill bagi siswa SMK Muhammadiyah 2 Cileungsi serta sebagai bentuk promosi dan kepedulian perguruan tinggi terhadap lingkungan. Berdasarkan hasil kuesioner kepuasan peserta pada Workshop Pengelolaan WordPress Website Management diperoleh data sebagai berikut Penyampaian Materi 92\% (Sangat Baik dan Baik) dan Manfaat Diklat bagi Peserta 94\% (Sangat Bermanfaat dan Bermanfaat), demikianlah pelatihan ini bisa bermanfaat dan disampaikan kepada peserta dengan kategori baik. Output dari kegiatan ini adalah peserta mampu mempublikasikan karya desain website yang dibuat melalui hosting dan domain, manual manajemen, jurnal, serta publikasi dan website media cetak. Harapan kami semoga apa yang kami lakukan dapat membawa dampak positif dan perubahan untuk kemajuan bangsa ini dan Kabupaten Cileungsi pada khususnya.
\end{abstract}

Kata Kunci: Pendidikan, Sekolah Vokasi, Kompetensi, Website, WordPress

\begin{tabular}{lcccc}
\hline MANAGEMENT & OF & WEBSITE & MANAGEMENT & IN \\
EMPOWERMENT & OF & VOCATIONAL & SCHOOL & OF \\
MUHAMMADIYAH & VOCATIONAL SCHOOLS & &
\end{tabular}

\begin{tabular}{l} 
ABSTRACT \\
\hline Every year SMK Muhammadiyah 2 Cileungsi graduates approximately \\
200 students, based on the results of interviews with several alumni that \\
\hline
\end{tabular}


not all school graduates are directly absorbed by the industrial world. SMK Muhammadiyah 2 Cileungsi has tried to find a solution by cooperating with several industries to absorb their graduates, but this is still not enough to increase the absorption of graduates, so that they can immediately earn income. The purpose of this Community Service (PkM) activity is how lecturers and students of the Muhammadiyah Cileungsi College of Technology can contribute to society, especially for vocational students to help hone and improve knowledge in the field of website programming, this activity is part of an effort to improve soft skills for students of SMK Muhammadiyah 2 Cileungsi as well as a form of promotion and higher education care for the environment. Based on the results of the participant satisfaction questionnaire at the Management WordPress Website Management Workshop, the following data were obtained. Submission of Material 92\% (Very Good and Good) and Training Benefits for Participants 94\% (Very Helpful and Beneficial), thus this training can be useful and delivered to participants by category well. The output of this activity is that participants are able to publish website design work made through hosting and domains, management manuals, journals, as well as print media publications and websites. We hope that what we do can have a positive impact and change for the progress of this nation and the Regency of Cileungsi in particular.

Keywords: Education, Vocational School, Competence, Website, WordPress

\section{PENDAHULUAN}

Sekolah Menengah Kejuruan (SMK) adalah salah satu bentuk satuan pendidikan formal yang menyelenggarakan pendidikan kejuruan pada jenjang pendidikan menengah sebagai lanjutan dari SMP/MTs atau bentuk lain yang sederajat atau lanjutan dari hasil belajar yang diakui sama/setara SMP/MTs [1]. Pendidikan kejuruan merupakan pendidikan menengah yang mempersiapkan peserta didik terutama untuk bekerja dalam bidang tertentu.[1].

SMK harus bisa menyiapkan lulusan berupa tenaga kerja yang terampil dalam berbagai ilmu tertentu sehingga bisa menyerap kebutuhan industri dan mengurangi tingkat pengangguran. Selain itu lulusan SMK diharapkan memiliki kemampuan dalam mengelola usaha (wirausaha), sesuai dengan kurikulum pembelajaran dengan adanya mata pelajaran kewirausahaan diharapkan siswa SMK bisa mempelajari kegiatan wirausaha dalam berbagai bidang.

Berdasarkan data Badan Pusat Statistik (BPS) bahwa berdasarkan tingkat pendidikan, Tingkat Pengangguran Terbuka (TPT) untuk SMK masih tertinggi diantara tingkat pendidikan lain, yaitu sebesar 8.63 persen [2]. Kegiatan wirausaha bisa menjadi salah satu faktor untuk mengurangi angka pengangguran tersebut, dengan berwirausaha maka lulusan tingkat SMK bisa menghadapi persaingan dan kebutuhan ekonomi.

Kecamatan Cileungsi merupakan kecamatan yang memiliki Sekolah SMK/SMK sederajat dengan angka yang cukup besar (SMA 6, SMK 28 dan MA 3) dalam sebuah kecamatan. Berdasarkan grafik diatas bisa dilihat bahwa jumlah SMK mencapai 4 kali lebih banyak dari SMA. Kegiatan Pengabdian kepada Masyarakat (PkM) ini akan ditujukan untuk siswa SMK dengan alasan karena siswa SMK berorientasi terhadap dunia industri atau kerja, SMK Muhammadiyah 2 Cileungsi akan menjadi mitra dalam PkM ini.

SMK Muhammadiyah 2 Cileungsi merupakan SMK yang memiliki 4 (empat) jurusan keahlian, yaitu Teknik Kendaraan Ringan (TKR), Teknik Komputer Jaringan (TKJ), Teknik Otomasi Industri 
dan Teknik Animasi, SMK Muhammadiyah 2 Cileungsi memiliki siswa yang cukup banyak lebih dari 600 untuk tiap tahunnya.

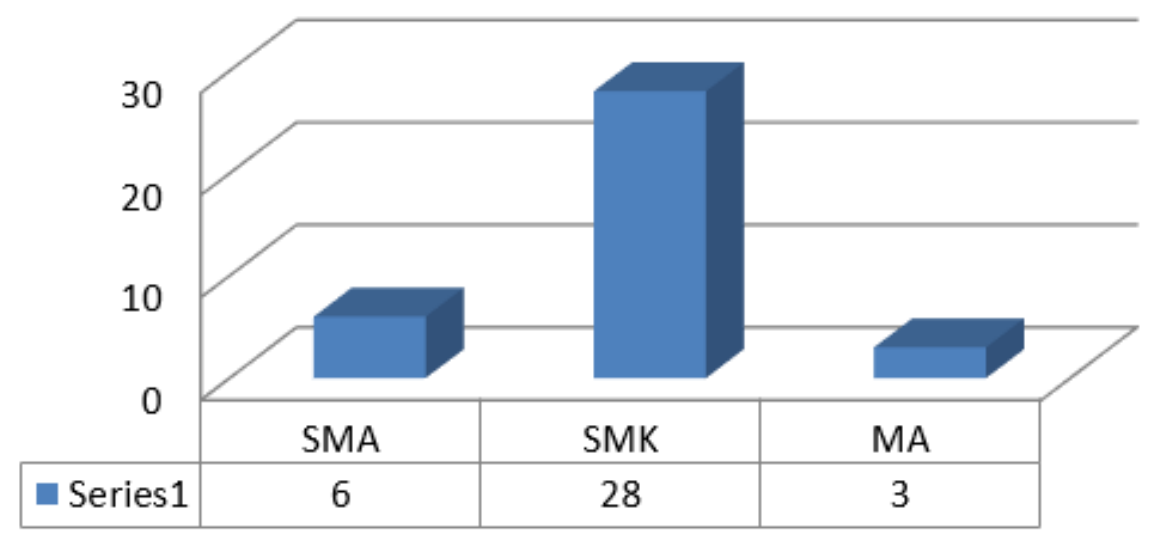

Gambar 1. Grafik jumlah pendidikan SMA/SMK sederajat di Kecamatan Cileungsi

(Sumber: referensi.data.kemdikbud.go.id)

SMK Muhammadiyah 2 Cileungsi beralamat di Jl. Akses Desa Dayeuh No. 97B, CileungsiBogor (Jarak kurang lebih $10 \mathrm{KM}$ dari STT Muhammadiyah Cileungsi).

\subsection{PERMASALAHAN MITRA}

Setiap tahun SMK Muhammadiyah 2 Cileungsi meluluskan kurang lebih 200 siswa, berdasarkan hasil wawancara dari dengan beberapa alumni bahwa tidak semua siswa lulusan sekolah langsung terserap oleh dunia industri. SMK Muhammadiyah 2 Cileungsi sudah mencoba mencari solusi dengan cara menggandeng beberapa industri untuk menyerap tenaga lulusannya, namun hal ini dirasa masih belum cukup untuk meningkatkan daya serap lulusan, untuk bisa langsung memiliki penghasilan.

Website metode untuk menampilkan informasi di internet, baik itu berupa teks, gambar, video \& suara maupun interaktif memiliki keuntungan yang menghubungkan (link) dari dokumen dengan dokumen lainnya (hypertext) yang dapat diakses melalui browser [3].

Salah satu profesi yang sedang ramai dibutuhkan dunia usaha dan dunia industri saat ini adalah pemrograman website, setiap perusahaan pasti memerlukan website untuk menampilkan profil dari perusahaannya tersebut, bidang ini sangat potensi untuk ditekuni bagi pelajar khususnya tingkat SMK.

Selain itu pelajar juga bisa belajar berwirausaha dengan membuka jasa pembuatan dan pengelolaan website, salah satu muatan kurikulum pendidikan adalah adanya mata pelajaran kewirausahaan, di dalam mata pelajaran tersebut diajarkan bagaimana siswa mengelola proses wirausaha dalam berbagai bidang, umumnya kegiatan ini meliputi kegiatan pengelolaan, manajemen, pemasaran baik produk maupun jasa.

Lulusan SMK harus menjadi seorang wirausaha untuk melakukan upaya-upaya kreatif dan inovatif dengan jalan mengembangkan ide dan meramu sumber daya untuk menemukan peluang dan perbaikan hidup [4]. Seorang wirausaha yang mengombinasikan faktor-faktor produksi seperti sumber daya alam, tenaga kerja, material dan peralatan lainnya untuk meningkatkan nilai yang lebih tinggi dari sebelumnya [5].

Ada banyak alasan, mengapa pada akhirnya kewirausahaan dijadikan sebuah ilmu yang diajarkan dalam dunia pendidikan. Pendidikan kewirausahaan telah diajarkan sebagai suatu disiplin ilmu yang independen, karena kewirausahaan:

a. Berisi bidang pengetahuan yang utuh dan nyata, yaitu terdapat teori, konsep dan metode ilmiah yang lengkap. 
b. Memiliki dua konsep, yaitu posisi permulaan dan perkembangan usaha.

c. Merupakan disiplin ilmu yang memiliki objek tersendiri, yaitu kemampuan menciptakan sesuatu yang baru dan berbeda.

d. Merupakan alat untuk menciptakan pemerataan usaha dan pendapatan atau kesejahteraan rakyat yang adil dan makmur.

\subsection{SOLUSI YANG DITAWARKAN}

Berdasarkan permasalahan diatas, maka kami mencoba mengadakan workshop manajemen dan pengelolaan website dalam rangka pemberdayaan pelajar SMK Muhammadiyah 2 Cileungsi, adapun target dari kegiatan ini.

a. Peserta memahami konsep dan etika bisnis jasa website.

b. Peserta menguasai teknik pembuatan dan pengelolaan website.

c. Peserta dapat meningkatkan softskill tentang pemrograman dalam pembuatan website.

d. Peserta bisa membuat company profile perusahaan atau instansi menggunakan website.

e. Peserta memiliki pengetahuan tambahan tentang web hosting dan domain.

\subsection{TARGET LUARAN}

Adapun target luaran Pengabdian kepada Masyarakat.

a. Adanya peningkatan soft skill bagi peserta.

b. Peserta memiliki website secara mandiri.

c. Karya tulis ilmiah berupa Jurnal.

d. Panduan Perancangan dan Pengelolaan Website.

\section{METODE PENGABDIAN}

Kegiatan Pengabdian kepada Masyarakat ini dilaksanakan setiap hari Sabtu pada tanggal 18, 25 Januari, 1 dan 8 Februari 2020 dengan peserta 60 orang dan dilaksanakan di SMK Muhammadiyah 2 Cileungsi. Adapun metode yang dilaksanakan berupa workshop berkelanjutan dengan rancangan target dan realisasi jadwal.

Adapun jadwal Pengabdian kepada Masyarakat ini dijelaskan pada tabel 1.

Tabel 1. Jadwal kegiatan.

\begin{tabular}{lll}
\hline Pertemuan Ke & Hari/Tanggal & Materi \\
\hline 1 & Sabtu, 18 Januari 2020 & Mengenal WordPress \\
& & Instalasi server lokal (Xampp) \\
& Instalasi WordPress \\
& Setting dan konfigurasi WordPress \\
& & Upload Plugin \\
& & Menu \\
& Sabtu, 25 Januari 2020 & Menambah Widget \\
& & Mengganti tema \\
& & Menambah kategori \\
& & Menambah link \\
& & Mengatur tampilan halaman dan posting \\
& Sabtu, 01 Februari 2020 & Edit gambar dan foto \\
& & Memasukkan media dan video \\
& & Mengelola komentar \\
& & Mengatur Permalinks \\
& & Responsive template (Bootstrap)
\end{tabular}


Upload Web ke hosting

Promosi dengan SEO

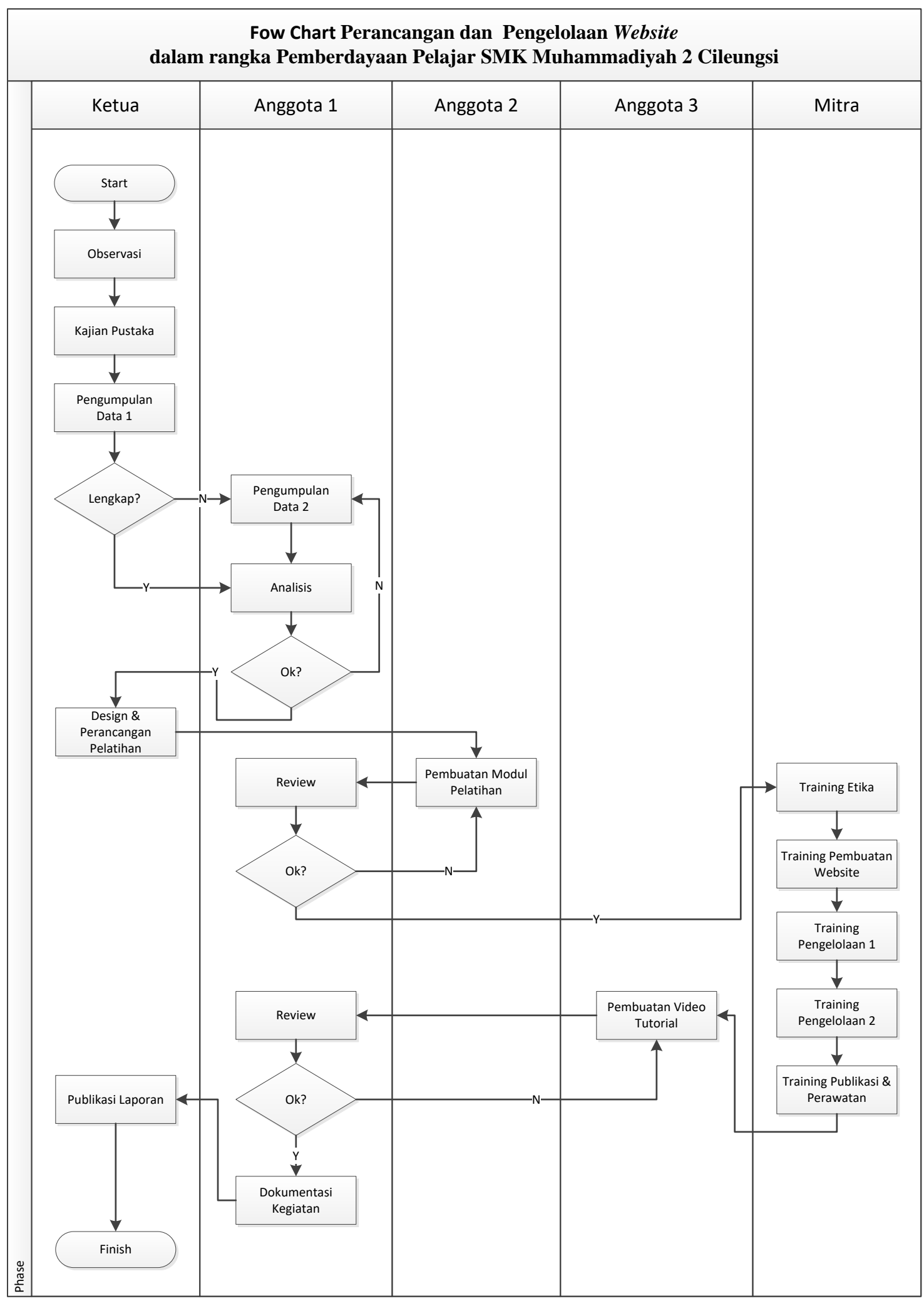

Gambar 2. Rancangan flowchart 


\section{HASIL DAN PEMBAHASAN PENGABDIAN}

Adapun berdasarkan hasil kuesioner (menggunakan google form) kepuasan atau pemahaman peserta terhadap workshop yang dilaksanakan.

3.1 Penyampaian Materi.

Pada gambar 3 dijelaskan kuesioner dari 36 tanggapan yang disampaikan oleh peserta pelatihan.

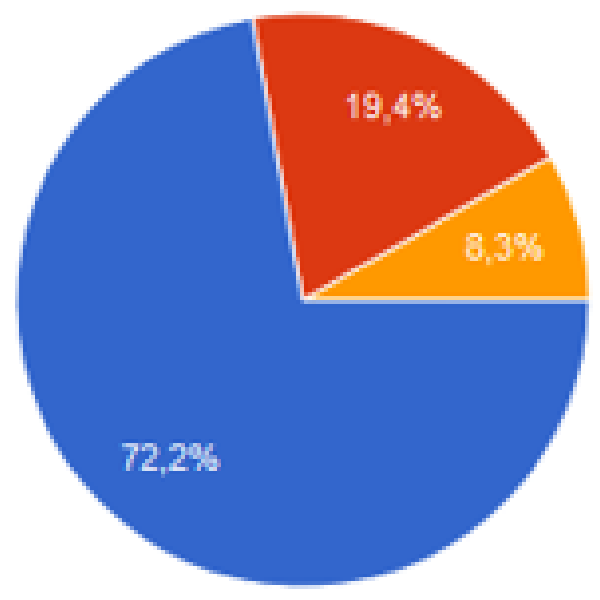

\section{Sangat Baik}

Baik

Cukup

Kurang

Gambar 3. Penyampaian materi

Berdasarkan gambar 3 mengenai kepuasan peserta (36 responden) terhadap materi yang disampaikan dalam acara workshop adalah sebagai berikut $72.2 \%$ Sangat Baik, 19.4\% Baik, 8.3\% Cukup.

\subsection{Ketersediaan Bahan Ajar (Modul/Panduan)}

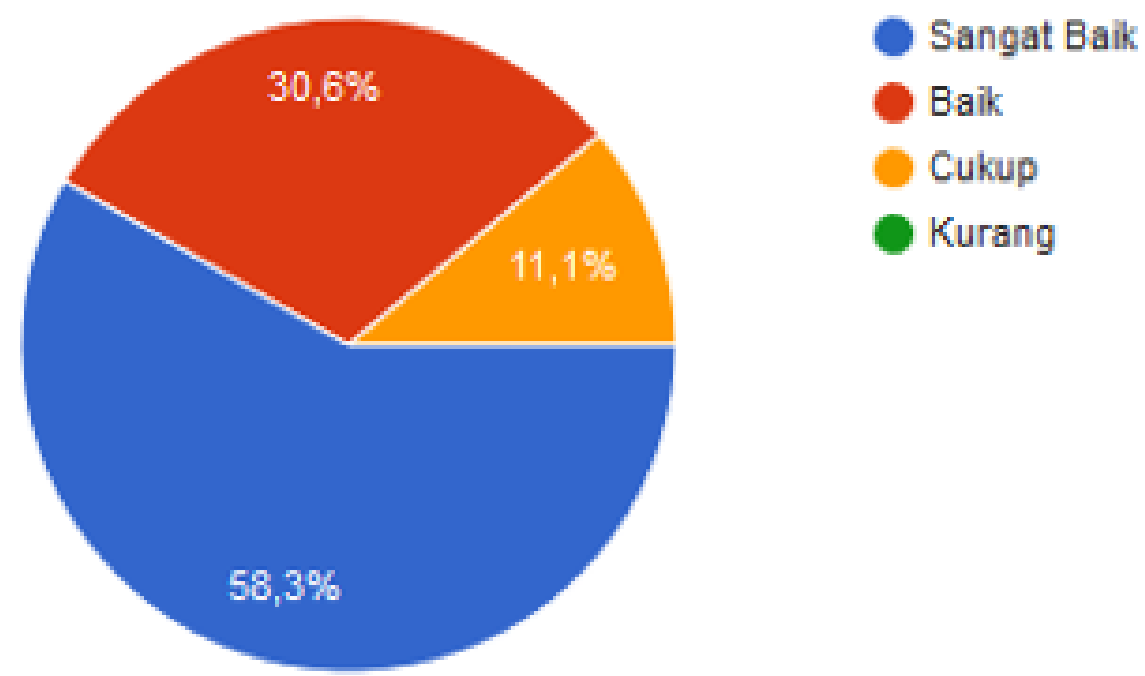

Gambar 4. Ketersediaan bahan ajar

Berdasarkan gambar 4 kepuasan peserta (36 responden) terhadap ketersediaan bahan ajar (Modul/Panduan) yang disampaikan dalam acara workshop adalah sebagai berikut 58.3\% Sangat Baik, $30.6 \%$ Baik, $11.1 \%$ Cukup. 
3.3 Pemahaman Peserta Terhadap Materi Yang Disampaikan

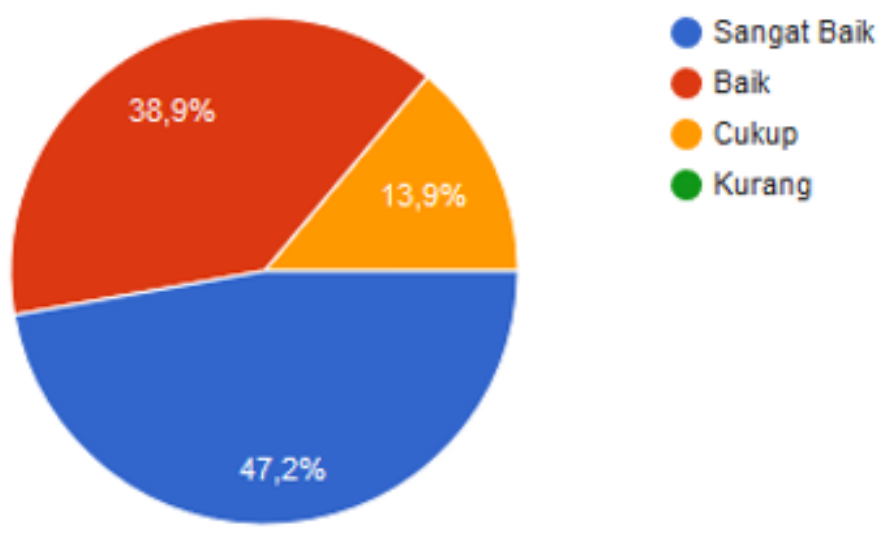

Gambar 5. Pemahaman peserta terhadap materi yang disampaikan

Berdasarkan gambar 5 kepuasan peserta (36 responden) tentang pemahaman peserta terhadap materi yang disampaikan dalam acara workshop adalah sebagai berikut $47.2 \%$ Sangat Baik, $38.9 \%$ Baik, $13.9 \%$ Cukup.

\subsection{Manfaat Pelatihan Bagi Peserta}

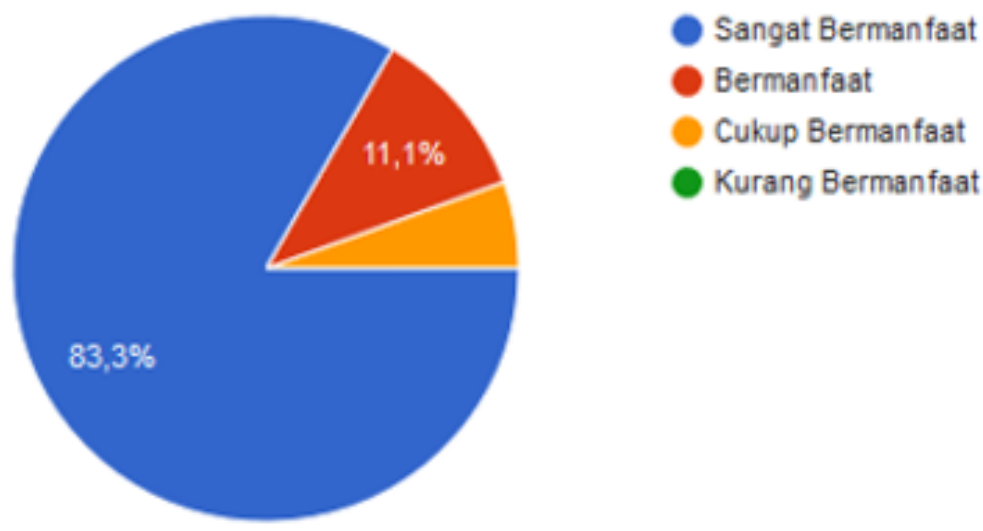

Gambar 6. Manfaat Pelatihan Bagi Peserta

Berdasarkan grafik diatas kepuasan peserta (36 responden) tentang pemahaman peserta terhadap materi yang disampaikan dalam acara workshop adalah sebagai berikut 47.2\% Sangat Baik, 38.9\% Baik, $13.9 \%$ Cukup.

\section{SIMPULAN}

Kegiatan Pengabdian kepada Masyarakat Sekolah Tinggi Teknologi Muhammadiyah Cileungsi telah dilaksanakan berupa workshop manajemen Website pengelolaan Wordpress bagi Siswa SMK Muhammadiyah 2 Cileungsi dengan jumlah peserta sebanyak 60 orang, adapun berdasarkan hasil dan pembahasan dapat disampaikan bahwa penyampaian materi 92\% (Sangat Baik dan Baik) dan manfaat pelatihan bagi peserta 94\% (Sangat Bermanfaat dan Bermanfaat), dengan demikian pelatihan ini dirasakan bermanfaat dan tersampaikan kepada peserta dengan kategori yang baik. Adapun saran yang dapat disampaikan semoga kegiatan bisa dilaksanakan kepada Instansi lainnya dengan jangkauan peserta yang lebih besar, misalnya untuk siswa tingkat SMK se Kecamatan Cileungsi dan untuk perbaikan kedepan materi yang telah disampaikan dapat diperbaiki dan ditambahkan agar menjadi lebih baik lagi. 
Manajemen Pengelolaan Website Dalam Rangka Pemberdayaan Pelajar Sekolah Menengah Kejuruan Muhammadiyah 2 Cileungsi

\section{UCAPAN TERIMA KASIH}

Ucapan Terima kasih kami sampaikan kepada seluruh pihak yang telah berkontribusi dalam acara ini diantaranya:

1. Ketua Sekolah Tinggi Teknologi Muhammadiyah Cileungsi

2. Wakil Ketua II Sekolah Tinggi Teknologi Muhammadiyah Cileungsi

3. Ketua LPPM Sekolah Tinggi Teknologi Muhammadiyah Cileungsi

4. Ketua Program Studi Teknik Informatika Sekolah Tinggi Teknologi Muhammadiyah Cileungsi

5. Kepala SMK Muhammadiyah 2 Cileungsi

6. Kepala Program dan Guru TKJ SMK Muhammadiyah 2 Cileungsi

7. Dosen dan Mahasiswa Team Pengabdian kepada Masyarakat Sekolah Tinggi Teknologi Muhammadiyah Cileungsi

8. Seluruh Peserta Siswa SMK Muhammadiyah 2 Cileungsi.

\section{DAFTAR PUSTAKA}

[1] K. Ristekdikti, "https://kelembagaan.ristekdikti.go.id," [Online]. Available: https://kelembagaan.ristekdikti.go.id/wpcontent/uploads/2016/12/permendiknas_39_2008_ttg_kesiswaan.pdf. [Accessed 1608 2019].

[2] B. P. Statistik, "www.bps.go.id," BPS, Februari 2019. [Online]. Available: https://www.bps.go.id/pressrelease/2019/05/06/1564/februari-2019--tingkat-pengangguranterbuka--tpt--sebesar-5-01-persen.html. [Accessed 2508 2019].

[3] R. H. M Yuhefizar, Cara Mudah Membangun Website Interaktif Menggunakan Content Management System Joomla, Jakarta: Elex Media Komputindo, 2009.

[4] S. Prawirokusumo, Kewirausahaan dan Manajemen Usaha Kecil, Yogyakarta: BPFE, 2010.

[5] Suryana, Kewirausahaan Pedoman Praktis: Kiat dan Proses Menuju Sukses, Edisi Ketiga, Jakarta: Salemba, 2006.

[6] PDSPK, "referensi.data.kemdikbud.go.id," Pusat Data Dan Statistik Pendidikan dan Kebudayaan (PDSPK) Kementerian Pendidikan dan Kebudayaan, 2019. [Online]. Available: https://referensi.data.kemdikbud.go.id/index11.php?level=3\&kode=020518\&id=15. [Accessed 25 Agustus 2019]. 